\title{
Economics of co-firing rice straw in coal power plants in Vietnam
}

\author{
Truong, A.H. $.^{1,3^{*}}, H a-D u o n g, .^{2,3}$, Hoang Anh Tran ${ }^{1,3}$ \\ ${ }^{1}$ University of Science and Technology of Hanoi (USTH), \\ Vietnam Academy of Science and Technology, Hanoi, Vietnam \\ ${ }^{2}$ Centre International de Recherche sur l'Environnement et le Développement (CIRED), CNRS, France \\ ${ }^{3}$ Vietnam Initiative for Energy Transition (VIET), Hanoi, Vietnam
}

2020-09-20

\begin{abstract}
As governments forced electricity producers to use more renewable energy sources, over a hundred thermal power plants in high-income countries turned to biomass as a partial or complete replacement for coal. Is the co-firing technology appropriate for Vietnam? To assess the technology we build an integrated model simulating the economics, environmental and social implications of blending $5 \%$ of rice straw in two existing coal power plants in Vietnam. The business value of co-firing is positive -straw is cheaper than coal- but not large enough to motivate the stakeholders. The external social benefit of co-firing -reduced air-borne pollutionare several times larger than the business value. Within that external benefit, the social value of avoided $\mathrm{PM}_{2.5}$ and $\mathrm{NO}_{\mathrm{x}}$ emissions dominates the social value of avoided $\mathrm{CO}_{2}$ emissions. The net job creation effect is positive: collecting straw creates more employment than using less coal destroys. This is the first technology assessment of co-firing biomass in coal power plants in Vietnam and one of the first for a subtropical middle-income country. The study only considers rice straw, and it does not address the role of government nor the biomass market functioning. The price of coal is the primary determinant of co-firing business value. There is an empirical economic justification for a public intervention to promote co-firing biomass in Vietnam, mainly as a way to reduce open-field straw burning. Local air quality goals, rather than greenhouse gas reduction policy, can justify such regulations.
\end{abstract}

* Corresponding author. Email: truonganha87@gmail.com 


\section{Highlights}

- There is a weak business case for co-firing rice straw and coal for power in Vietnam.

- Considering externalities makes co-firing much more interesting socially.

- Co-firing improves local air quality by reducing open field burning.

- For Vietnam, co-firing benefits from reducing $\mathrm{NO}_{\mathrm{x}}$ and $\mathrm{PM}_{2.5}$ emissions dominate $\mathrm{CO}_{2}$ emission reduction.

- Most jobs created by co-firing are for straw collection.

\section{Keywords}

Co-firing economics; emission reductions; air pollution; open-burning; rice residues management

\section{Document statistics, all inclusive}

Words count 11357 words, tables count 7, images count 5 .

\section{List of abbreviations, units and nomenclature}

$\begin{array}{ll}\text { GHG } & \text { Greenhouse gas } \\ \text { IPCC } & \text { Intergovernmental Panel on Climate Change } \\ \text { NPV } & \text { Net Present Value } \\ \text { UK } & \text { The United Kingdom } \\ \text { US } & \text { The United States of America } \\ \text { GW } & \text { Gigawatt }=10^{9} \text { Watt } \\ \text { MW } & \text { Megawatt }=10^{6} \text { Watt } \\ \text { kWh } & \text { kilowatt hour }=10^{3} \text { Watt-hour } \\ \text { MWh } & \text { Megawatt hour }=10^{6} \text { Watt-hour } \\ \text { MJ } & \text { Megajoule }=10^{6} \text { Joule } \\ \text { t } & \text { ton }=10^{3} \mathrm{~kg} \\ Q & \text { Quantity of straw required for co-firing } \\ Q_{\text {Coal }} & \text { Quantity of coal used at the plant with co-firing (Ex-post }) \\ Q_{\text {Coal }}^{0} & \text { Quantity of coal used without co-firing (Ex-ante })\end{array}$


$Q_{\text {elec }}$

$p_{1} \quad$ Straw price purchased from farmers

$p_{2} \quad$ Straw price sell at the plant gate

$p_{\text {elec }} \quad$ Electricity purchase price

$p_{\text {coal } \quad \text { Coal price }}$

$\pi_{\text {farmer }}$

$\pi_{\text {reseller }}$

$\pi_{\text {plant }}$

$\pi_{\text {farmer }}^{0}$

$\pi_{\text {reseller }}^{0}$

$\pi_{\text {plant }}^{0}$

$C_{\text {collect }}$

$C_{\text {reseller }}$

$C_{\text {transport }}$

$C_{i n v}$

$C_{O M}$

$C_{O M}^{0}$

WTA

WTP

V

Ex-post economic result of farmer

Ex-post economic result of reseller

Ex-post economic result of plant

Ex-ante economic result of farmer

Ex-ante economic result of reseller

Ex-ante economic result of plant

Total collection cost of rice straw

Total cost for transportation of straw

Investment cost for co-firing

Farmer's willingness to accept

Plant's willingness to pay
Quantity of annual electricity generation

Total costs for handling and transporting straw

Ex-post operation and maintenance cost

Ex-ante operation and maintenance cost

Magnitude of the business opportunity for co-firing value chain 


\section{Introduction}

Co-firing means burning different fuels together. More specifically, here, co-firing refers to burning biomass with coal in a power plant. The aim of deploying co-firing technology is to reduce greenhouse gas (GHG) and pollutants emissions from burning coal [1-3]. Co-firing can reduce GHG and air pollutants through several processes such as offset coal combustion in the plants, avoided coal mining, and reduced biomass open-air burning. A life cycle assessment of co-firing wood pellets at 10\% mixing rate in the United States reports a GHG emissions reduction of $9 \%$ [4].

Tillman [5] argues that co-firing is the most cost-effective way to use biomass in the electricity generation industry. Co-firing is the cheapest option among the biomass power generation technology when it comes to equipment costs (ranging from $100-600 \mathrm{USD} / \mathrm{kW}$ compared to 900 up to $6000 \mathrm{USD} / \mathrm{kW}$ ) [6]. Co-firing a modest fraction of biomass in a large coal-burning power plant, using existing equipment such as boilers, feeding systems, turbines, and generators, is usually cheaper than building a new biomass-only power plant [7]. The technology is technically feasible under $20 \%$ of mixing rate, without creating any issues with unburned carbon materials and auto-ignition[8]. Moreover, co-firing mitigates the risk of biomass supply discontinuity, as far as the plant can still run on $100 \%$ coal if necessary. The IEA inventory [9] lists over 150 power plants worldwide with experience in this technology. Many projects in Europe and North America co-fire woody biomass with coal at mixing ratios up to $10 \%$ in terms of fuel heat content.

In Vietnam, a country with over 130 TWh of biomass theoretical potential for power generation [10], co-firing technology is not yet deployed. Vietnam was ranked ninth globally by the amount of electricity generated from coal power plants [11] in 2020 with $21 \mathrm{GW}$ of coal power installed capacity, accounting for $30 \%$ of the total capacity of Vietnam's power system [12]. The increase of coal fleets has raised the level of greenhouse gas (GHG) emission in power sector. Estimated emissions from power sector in 2020 was $207.5 \mathrm{MtCO}_{2} \mathrm{e}$, a $132.1 \mathrm{MtCO}_{2} \mathrm{e}$ increase compared to the inventory in 2014 [13]. This is mostly contributed by coal power plants with $12 \mathrm{GW}$ added capacity in the period [12,14]. Since coal power plants are major contributor to Vietnam's GHG emissions, it is worth to further investigate co-firing technology as one of the mitigation measures.

Many kinds of biomass can be co-fired: straws, husks, wood chips, pellets, even some fractions of municipal solid waste. We selected rice straw because of its abundance in Vietnam [15]. Rice straw production in 2017 is estimated to be $42 \mathrm{Mt}$, equivalent to a theoretical potential (total amount of energy stored in the material) of 500 PJ, accounting for half of the total theoretical potential of agricultural residues [10]. In Vietnam, rice straw waste management is an issue when the most common way of rice straw disposal is open burning [16,17], causing serious air pollution during harvesting seasons.

International experiences in co-firing rice straw [18] have demonstrated technological feasibility. Nevertheless, there is no co-firing facility to date in Vietnam. Yet, the government is 
considering the mandate of renewable portfolio standards in the power sector, and international experience shows that such policies can lead utilities to adopt co-firing.

This study investigates the economic feasibility of co-firing in Vietnam, focusing on rice straw in coal power plants. To assess the co-firing technology in the context of Vietnam, we use an integrated life-cycle-assessment method. Using a standard approach in applied economics, we first build a formal, stylized model, then implement it numerically. Figure 1 illustrates the system. Its boundaries include the straw production, transport, and use. The results evaluated are the financial, employment, and environmental consequences ex-post of co-firing $5 \%$ of rice straw with coal on a heat basis compared to an ex-ante $100 \%$ coal baseline. To explore the heterogeneity of coal power plants, we explore two different cases. One is a newly constructed $1080 \mathrm{MW}$ plant with a fluidized bed boiler, Mong Duong 1. The other is an old $100 \mathrm{MW}$ plant with pulverized coal boiler, Ninh Binh. Both plants are located in the North of Vietnam, where most of the coal industry lies.

This manuscript's outline is as follows: Section 2 reviews how co-firing was made economically feasible in some countries. Section 3 reviews the industrial economics of co-firing projects, to show there is a research gap when it comes to a projects in tropical middle-income countries like Vietnam. Section 4 presents the stylized economic model on the market with three actors. It derives theoretically the condition under which co-firing has a positive business value, meaning that it is economically feasible. Section 5 implements the model empirically, extending it to account for externalities according to the Life Cycle Analysis approach. Section 6 presents results on the business value, showing that the technology could be weakly profitable under current technical and market conditions. Section 7 presents results on air pollutant emissions, indicating that the value of external benefits is positive and several times larger than the business value. Section 8 presents results quantifying job creation -showing that they occur primarily in the farming sector. Section 9 summarizes the take-home findings and briefly discusses their policy implications to conclude. 


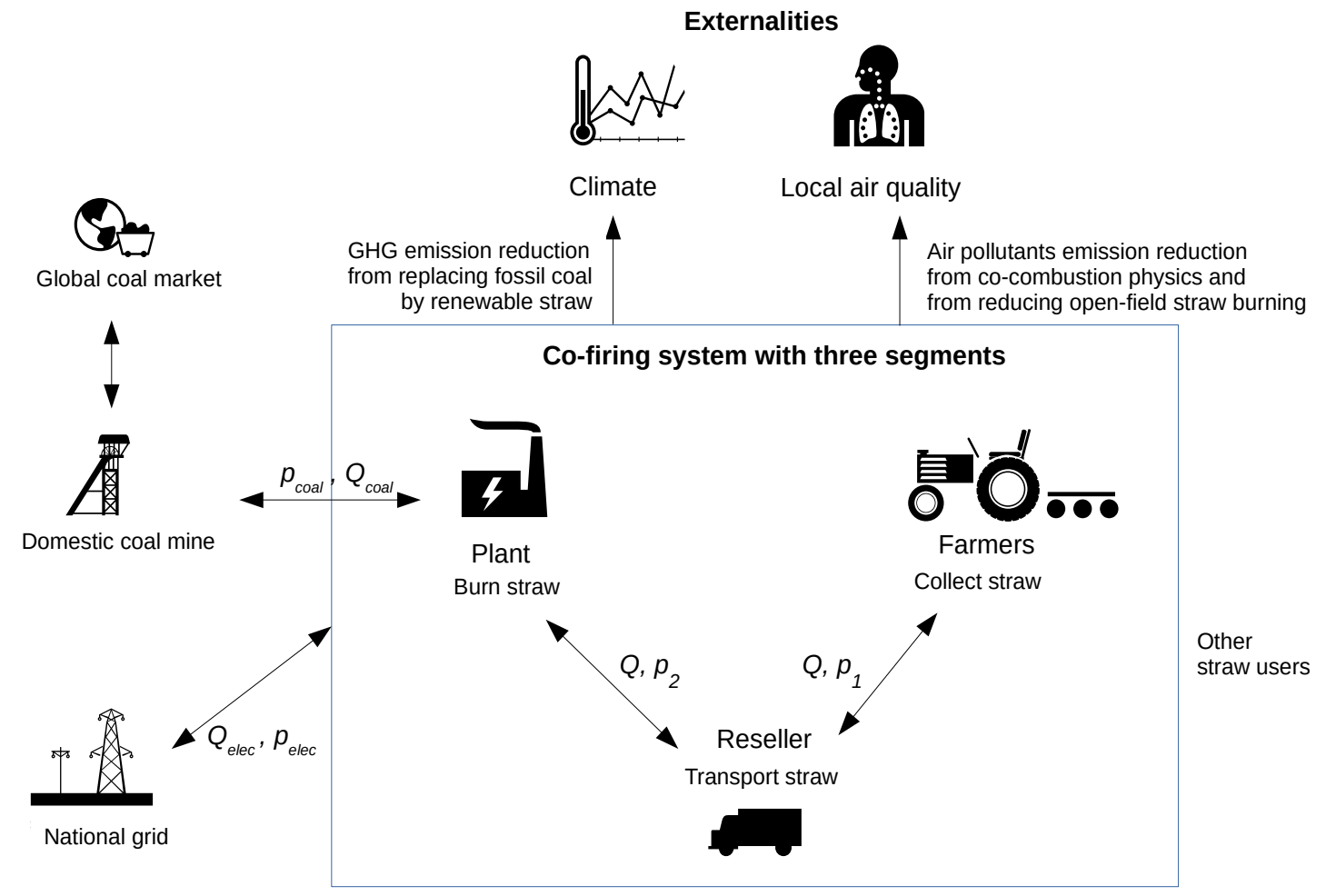

Figure 1. Diagram of the co-firing system with its immediate externalities

6 


\section{How biomass co-firing was made economically viable?}

International experience shows that co-firing is economically viable under various national supporting schemes. Besides direct command and control, regulation instruments include (i) carbon taxes; (ii) feed-in tariffs; (iii) direct subsidies; (iv) renewable portfolio standards which impose a minimum fraction of renewable energy in the production of electricity [19-21].

Carbon taxes have not solved climate change, but the social value of carbon remains a valid theoretical indicator to benchmark greenhouse gas emission reduction policies, plans, and programs. [22] summarized the supporting level for co-firing in some European countries ranging from 20 to 64 Euro/MWh through both Feed-in Tariff and Green Certificates schemes. [23] have shown that a value of avoided $\mathrm{CO}_{2}$ of $30 € / \mathrm{t}$ would make co-firing biomass in hard coal power plants economically viable in Germany. More recently, when evaluating the prospect of co-firing in four European countries, [2] concluded that a carbon price at $5 € / t$ would make cofiring with biomass prices lower than $2.3 € / G J$ profitable. A carbon price higher than $50 € / \mathrm{t}$ would enable the use of pellets.

The three other categories of instruments have been used with success to promote biomass energy:

In the UK, a Renewable Obligation scheme pushed co-firing projects forward. The renewable obligation for electricity suppliers in England \& Wales and Scotland started at 2\% in 2002 and increased to $48.4 \%$ in 2019-2020 [24]. The certificates issued for the amount of electricity generated from renewable resources are tradable. The share of co-firing in renewable energy generation in the UK snowballed after introducing the renewable obligation. By 2017, when the scheme was closed to new capacity and replaced by a Contract for difference mechanism, all major coal power plants in the UK were retrofitted for co-firing [21]. While the scheme was introduced technology-neutral, this was not the case after 2009. As the scheme discouraged cofiring at low biomass percentage after 2012, coal power plants responded by switching to dedicated biomass units.

Similarly, South Korea introduced in 2012 a Renewable Portfolio Standard to mandate the minimum share of renewable for generation facilities together with the issuance of tradable Renewable Energy Certificates to initiate the deployment of co-firing. The obligatory renewable service supply ratio increases from $2 \%$ in 2012 to $8 \%$ in 2020 , going up by $1 \%$ per year. It is not technology-neutral, and biomass energy counts at $150 \%$ of its nominal value - solar and wind energy producers are going to court over this. After the UK, South Korea was the second-largest market for industrial wood pellets in 2020 [25].

Denmark and The Netherlands choose a different approach. They directly subsidize co-firing for power generation. Denmark pays a subsidy of 2 Eurocent $/ \mathrm{kWh}$ for both dedicated and co-firing plants since January 2009 [26]. The Netherlands adds a feed-in premium to the wholesale price for electricity generated from co-firing, subject to sustainability criteria after 2013 [27]. In 2020, 
Denmark and the Netherlands were the third and fifth largest markets for industrial wood pellets [25].

Japan initially adopted a renewable portfolio standards scheme in 2003 but replaced it with a combined mandate renewable share with feed-in tariff in 2012. Power producers must generate a part of their electricity from renewable resources. They receive a fixed electricity purchase price with a fixed-term contract to do so. Japan's feed-in tariff for biomass power generation ranges from $13.65-33.6 \mathrm{yen} / \mathrm{kW}$, depending on the kind of biomass used. The renewable portfolio standard helped to increase the biomass power generation capacity from $1.3 \mathrm{GW}$ in 2004 to $2.3 \mathrm{GW}$ in 2011 . Under the feed-in tariff scheme, biomass power capacity reached 3.5 GW in 2018. Co-firing plants account for most approved biomass power projects (123/166) [28]. Japan was the fourth market for industrial wood pellets in 2020. Strauss [25] suggests that its demand will increase faster than any other country over the next few years.

While co-firing pellets shipped from the international market is convenient, other countries are basing their biomass co-firing strategy on domestic resources. For example, German power plants co-fire mostly sewage sludge and waste material. Its 2019 Climate Package does not promote biomass co-firing [29]. For the US, Mei and Wetzstein [30] argued that the cost of domestic wood pellets was competitive with the import price but that it was too high to make co-firing commercially viable. Solar, wind and natural gas dominate biomass as energy sources to produce electricity in the US [31 table 7.2a]. Canada also has a thriving wood pellets export industry. Canada's electricity is mainly hydro-power-based, not biomass [32]. Nevertheless, the 205 MW Atikokan Generating Station in Ontario is the largest $100 \%$ biomass-fueled plant in North America, all from local producers [33].

All the cases mentioned so far are from high-income countries. As of 2020 , very few middleincome countries practice co-firing. Nevertheless, there is a technical potential for co-firing biomass along with coal in their power plants. That potential will only increase in relative importance. Many affluent countries are replacing their old coal plants with renewable energy. Middle-income countries have younger power plants and more constrained budgets.

Consider rice straw, the top nine rice-producing countries globally [34] - China, India, Indonesia, Bangladesh, Vietnam, Thailand, Myanmar, Philippines, Brazil - are all middleincome. Seven of these nine countries are major coal users in the top 32 coal consuming countries in the world. The remaining two - Bangladesh and Myanmar - officially plan to build coal power plants.

[35] recognized many years ago that among the countries listed above, only Indonesia and Thailand tried co-firing biomass with coal at only one or two plants. The situation has not evolved much in Thailand, while Indonesia warmed up to the technology in recent years.

While biomass co-firing deployment in ASEAN remains limited, there are positive talks [36]. Early 2020, Indonesia was still studying resource potentials and demonstrating the technology. However, the government's goal to achieve $23 \%$ of renewable energy by 2025 may increase its adoption [37]. Thailand's 2015 Alternative Energy Development Plan [38] does not mention co- 
firing. The Mae Moh power plant only conducts co-firing research, not implementation. However, new five years plans will start in 2020. At the moment, co-firing in Vietnam power plants means blending foreign coal with domestic coal. However, renewable portfolio standards that include biomass are on the table for the next revision of the power development plan and national energy strategy. The Philippines have a very liberalized power generation market. There are few public incentives for co-firing. However, one large utility -SMC Global Energydiscussed using rice husk at two $600 \mathrm{MW}$ coal-fired power generation units [39].

In China, an overwhelming share of electricity is generated from coal. China is pursuing a vigorous low-carbon transformation. New wind and solar electricity cannot replace all the recently built coal power plants within the next ten years. Co-firing can play a role in this context, and China plans 89 co-firing pilot demonstration projects [40]. In Brazil, 4\% of electricity comes from biomass while only $1 \%$ comes from coal. The power development plan to 2027 [41] aims to keep the share of coal stable and develop biomass for decentralized power generation. That plan does not mention co-firing. In India, the Ministry of Power issued a Policy document towards co-firing 5-10\% biomass in both pulverized coal and fluidized bed units [42]. The National Thermal Power Corporation has demonstrated the feasibility at the industrial scale, and regulators are integrating co-firing into the Renewable Purchase Obligation system [43].

To sum up, rich countries have validated the technological and economic viability of co-firing biomass and coal in power plants. As the more affluent countries announced their plan to phase out coal, the market for co-firing moves to middle-income countries. Vietnam has built scores of coal power plants over the last 15 years. The urgent need to reduce their pollution levels motivates our study.

\section{Literature review: Biomass co-firing projects economics}

Studies on economics of co-firing were focused on the European or North America context. [44] looks at how Alberta's generation mix would be altered by deploying co-firing with wood pellet under different policies (carbon tax and Feed-in tariff). The modelling results show that the coal capacity of $5795 \mathrm{MW}$ could be reduced to $359 \mathrm{MW}$ as carbon tax increases from 0 \$ to $200 \$ / \mathrm{tCO}_{2}$. At a carbon tax of $50 \$ / \mathrm{tCO}_{2}$, co-firing at $15 \%$ is economically viable for $3398 \mathrm{MW}$ of coal capacity. Feed-in tariff for biomass at 60\$/MWh resulted in retrofitting in call coal power capacity and lower generation cost of Alberta's power system compared to carbon tax policy (but higher than if no additional policy in place). However, considering abatement cost of carbon emissions, carbon tax is more cost effective instrument. Without additional policy, the optimization resulted in $495 \mathrm{MW}$ converted to co-fire and $1523 \mathrm{MW}$ shut down to meet the requirement on emission intensity.

In Germany, [23] analysis the economic viability of co-firing various mix of biomass in new hard coal power plants based on full cost and Net Present Value (NPV), similar to what we do here. The results show that a low percentage mix of cheap biomass (1.4\% straw and $0.13 \%$ sewage sludge) slightly reduce $(-0.08 \%)$ the full cost compared to coal-only while a higher percentage mix of more expensive biomass (\%5 wood, $5 \%$ wood pellet, $1.4 \%$ and $0.13 \%$ sewage sludge) 
increases full cost by $0.2 \%$. The NPV calculation with a $\mathrm{CO}_{2}$ price at $30.6 \mathrm{Euro} / \mathrm{t}$ shows a positive different between co-firing and coal-only cases, indicating co-firing is economically viable at this level of carbon value. Higher percentage of biomass resulted in higher profitability.

Studies on biomass power in Vietnam are mostly on the dedicated biomass power plant $[45,46]$. Existing literature on co-firing in Vietnam remain very limited. A study conducted in 2019 [47] looked at the techno-economic potential of co-firing rice residues in Vietnam in reducing greenhouse gas emission from a national perspective. The study, however, not yet answer the question on what stake would be for the individual plants to deploy the technology. To the best of our knowledge, there are no study on the economic feasibility of co-firing rice straw in Vietnam. Hence, there is a knowledge gap for understanding the economic viability of co-firing in the country from the perspective of different stakeholders such as plant owner and biomass supplier, which this study aims to fill.

For other Southeast Asian countries with with similar context to Vietnam - rich in biomass resources and have strong coal fleet - such as Thailand, Indonesia and Malaysia, existing literature mostly focus on the experimental aspect of co-combustion technology [48,49]. One study [50] provided techno-economic assessment on scaling up coal with palm-oil, a feedstock that not available in Vietnam. A recent publication [51] looked at the economic and financial aspect of co-firing $5 \%$ of saw dust in a $660 \mathrm{MW}$ coal power plant by calculating the cost of producing $1 \mathrm{kWh}$ by co-firing compared to coal-fired only. The results show that a fuel cost saving of $2.5 \mathrm{M} \$ / \mathrm{y}$ is obtained. The study does not consider retrofitting cost, biomass transportation cost or operation and maintenance cost associated with co-firing. A closest literature on economic of co-firing investigated the life cycle assessment of co-firing rice straw in Malaysia [52]. It shows that without $\mathrm{CO}_{2}$ emission credit, the cost for co-firing is $93.29 \%$ higher than that of using coal. Although the study is quite comprehensive, the economic analysis just looked at the costs in relation to co-firing ratio. But contrary to what we do here, it did not provide the conditions for co-firing to be economically viable as a sector. We review the economics of co-firing, including the economics of key stakeholders involved in the co-firing value chain and the associated externalities to macroeconomics, local air quality and climate change.

\section{Theoretical economic model}

This section presents a fundamental financial model of the co-firing value chain. It derives the condition under which co-firing can be economically feasible. By economic feasibility, we mean that all stakeholders in the value chain can profit from co-firing. The stylized market involves three segments. As Figure 1 shows in the box, the three actors directly involved in the rice straw co-firing value chain are farmers, an intermediate logistics reseller company, and a power plant company.

To derive the feasibility conditions, we compare two situations. The ex-ante situation is the case without co-firing. Farmers dispose of straw as waste by burning it in the field. Equation 1 assumes that burning the straw on the field imposes no costs to the farmers. The power plant 
uses only coal to produce electricity. The ex-post situation is the case with an established straw co-firing value chain. The farmers collect a quantity of straw $Q$ from the fields. The reseller purchases straw from the farmers at price $p_{1}$, transports it, and resells it to the plant at a higher price $p_{2}$. The mass of coal used at the plant $Q_{\text {Coal }}$ is lower ex-post. With a superscript zero to denote the ex-ante values: $Q_{\text {Coal }}<Q_{\text {Coal }}^{0}$.

Let $\pi_{\text {farmer }}, \pi_{\text {reseller }}$, and $\pi_{\text {plant }}$ denote the ex-post economic result of each segment in the value chain. The economic feasibility condition is that $\pi>\pi^{0}$. for all three segments. Let us formalize the condition for the farmers, the reseller, and the plant.

To formalize the farmers' situation, let $C_{\text {collect }}$ denotes the total collection cost of straw, then:

Equation 1: $\quad \pi_{\text {farmer }}-\pi_{\text {farmer }}^{0}=p_{1} Q-C_{\text {collect }}$

Then $\pi_{\text {farmer }}>\pi_{\text {farmer }}^{0}$ is equivalent to:

Equation 2: $\quad p_{1}>C_{\text {collect }} / Q$

The farmers will have a positive benefit from collecting and selling straw when they can sell straw at a higher price than its average collection cost. The right-hand side of Equation 2 is the farmers' willingness to accept:

Equation 3: $\quad W T A=C_{\text {collect }} / Q$

This discussion can be represented graphically in a plane with the price of biomass horizontally and the additional profit vertically, see Figure 2, Equation 1 is a straight line (drawn in green) with a positive slope $Q$. The line intercepts the horizontal axis at WTA. As long as the point representing $p_{1}$ is to the right of the point representing WTA, then the farmer's gain will be positive. The line also intercepts the vertical axis at $-C_{\text {collect }}$.

Let us turn to the reseller. Let $C_{\text {reseller }}$ denotes its total operating costs for handling and transporting straw (see Supplementary material - Section 3). Its total gain is:

Equation 4: $\quad \pi_{\text {reseller }}-\pi_{\text {reseller }}^{0}=p_{2} Q-p_{1} Q-C_{\text {reseller }}$

Then $\pi_{\text {reseller }}>\pi_{\text {reseller }}^{0}$ is equivalent to:

Equation 5: $\quad p_{2}-p_{1}>C_{\text {reseller }} / Q$

To be interested, the reseller must mark up the prices enough to cover its average operating cost.

Figure 2, if we represent both $p_{1}$ and $p_{2}$ with points on the horizontal axis, then the second point must be to the right, at a distance greater than $C_{\text {reseller }} / Q$. We represent this constraint by a blue horizontal bar whose width is $C_{\text {reseller }} / Q$.

We model the power plant perspective with a bit more detail. We assume, as Figure 1 shows, that parameters $p_{\text {elec }}$, and $p_{\text {coal }}$ are exogenous, and unchanged ex-antelex-post. Let $C_{i n v}$ denotes the investment cost for co-firing. Ex-post, costs of Operation and Maintenance for the plant is assumed to be increased, we denote that $C_{O M}>C_{O M}^{0}$.

Profit of the plant is represented by Equation 6 ex-ante, Equation 7 ex-post: 
Equation 6: $\quad \pi_{\text {plant }}^{0}=p_{\text {elec }} Q_{\text {elec }}-p_{\text {coal }} Q_{\text {coal }}^{0}-C_{O M}^{0}$

Equation 7: $\pi_{\text {plant }}=p_{\text {elec }} Q_{\text {elec }}-p_{\text {coal }} Q_{\text {coal }}-p_{2} Q-C_{O M}-C_{\text {inv }}$

It follows that $\pi_{\text {plant }}>\pi_{\text {plant }}^{0}$ whenever:

Equation 8: $\quad p_{\text {coal }}\left(Q_{\text {coal }}^{0}-Q_{\text {coal }}\right)>p_{2} Q+\left(C_{O M}-C_{O M}^{0}\right)+C_{i n v}$

Co-firing is profitable when the value of coal saved is larger than the cost of co-firing, including biomass fuel cost, additional O\&M costs, and investment. Solving this inequality for $p_{2}$ yields the maximum price that the power plant is willing to pay:

Equation 9: $\quad W T P=p_{\text {coal }} \frac{Q_{\text {coal }}^{0}-Q_{\text {coal }}}{Q}-\frac{C_{O M}-C_{O M}^{0}}{Q}-\frac{C_{\text {inv }}}{Q}$

In Figure 2, the plant's additional profit ex-post, $\pi_{\text {plant }}-\pi_{\text {plant }}^{0}$, is represented as a function of $p_{2}$ by a downward sloping line. The line intercepts the horizontal axis at WTP. As long as the point representing $p_{2}$ is to the left of the point representing WTP, then the plant's gain will be positive.

The economic feasibility conditions are $p_{1}>W T A, p_{2}<W T P$, and $p_{2}-p_{1}>C_{\text {transport }} / Q$. The prices $\left(p_{1}, p_{2}\right)$ satisfying these conditions exist if and only if $W T P-W T A>C_{\text {transport }} / Q$. This inequality is equivalent to the following quantity $V$ being positive:

Equation 10: $V=p_{\text {coal }}\left(Q_{\text {coal }}^{0}-Q_{\text {coal }}\right)-C_{\text {collect }}-C_{\text {transport }}-C_{\text {inv }}-\left(C_{O M}-C_{O M}^{0}\right)$

This equation defines $V$ as the value of coal saved, minus: the technical costs to source biomass, the investment to adapt the plant facilities, and the new operation and maintenance costs. This $V$ is the magnitude of the business opportunity for the co-firing value chain. Prices $\left(p_{1}, p_{2}\right)$ do not influence the size of the cake $V$. They only determine how it is shared.

The co-firing market fundamental equation is $V>0$. Satisfaction of the market fundamental condition is not necessary nor sufficient to predict if a market will emerge. It can be insufficient for many reasons. To interest the farmer, there is another condition that the price of straw sold for co-firing should be higher than the price of straw sold for other purposes. On the opposite side of the market, straw competes with other biomass fuels. Power plants might prefer pellets. Finally, $V$ may be positive but not enough to motivate the actors, considering the risk levels to implement a new value chain. The empirical model developed below will show that this is indeed the case.

The fundamental market condition $V>0$ may not be necessary either. A power generation company may be interested in buying biomass simply because they are legally required to use renewable energy, and co-firing is the cheapest way to comply compared to other sources. The empirical model will show that external benefits justify regulation. In this case, Equation 10 indicates in which direction the market forces push for or against co-firing and how strong the push is. If $V$ is positive and large compared to stakeholder's other incomes, then there is a powerful incentive for the stakeholders to agree to set up the system and share the profits. In 
this case, only a small policy nudge may be necessary to make it happen. If the economic feasibility condition does not hold, then any co-firing promotion policy will be hard to enact.

\section{Empirical parameters for the empirical life-cycle analysis model}

We build an empirical model to explore the economic opportunity of co-firing rice straw in coal power plants. It implements the business model equations described in section 4 , with an annual time step, including investment in the first year, taxes, and depreciation. The model also accounts for the externalities presented in Figure 1: greenhouse gas emissions, local air pollutant emissions, and the coal supply chain.

Supplementary material - Section 5 shows parameters. They are based on the available technical and socioeconomic information from existing literature and from interviewing plant personnel. Supplementary material - Section 2 describes in pseudocode the numerical implementation of the model, and provides the link to the open-source code used to produce the results discussed below. Compared to the previous model version used in [53], the main changes are code cleanup, additional tables and figures, sensitivity analysis, updated rice production statistics to 2017, and relaxing the assumption that the reseller operates at no profit. The model's key assumptions are:

Direct co-firing is the technology selected since it is the cheapest, simplest, and most common co-firing technology [7]. The co-firing ratio is $5 \%$ on a heat basis, a representative order of magnitude for direct co-firing [54]. We assess the implications of co-firing by comparing an exante situation where only coal is used with an ex-post situation where a small percentage of biomass is co-fired, keeping the electricity production equal in the two situations. The boiler efficiency loss due to biomass co-firing follows Tillman [5 eq. 1]. With these assumptions, the mass of straw $Q$ co-fired is:

Equation $11 \quad Q=\frac{Q_{\text {elec }}}{\text { Plant efficiency }} \times 3.6 \frac{\text { Cofiring ratio }}{\text { Heat value of straw }}$

Where the Heat value of straw is in $\mathrm{MJ} / \mathrm{kg}$, the annual power generation $Q_{\text {elec }}$ is in $\mathrm{kWh}$, the plant efficiency is ex-post in the co-firing situation, the co-firing ratio is $5 \%$ on a heat basis, and factor 3.6 converts kWh to MJ. The amounts of coal used ex-post $Q_{\text {coal }}$ and ex-ante $Q_{\text {coal }}^{0}$ are derived using the same arguments.

Biomass is sourced locally. Rice straw is selected as biomass feedstock because this is the most abundant agricultural waste in Vietnam. We assume that farmers do not invest but rent in the straw winder machine to collect straw from the field. The total collection cost is labour cost, plus winder rental cost, plus fuel cost.

We assume the straw is transported by trucks, as typical in the North of Vietnam. We assume that transporters do not invest but rent, as logistics reuses the existing rice supply chain [55]. The total transportation cost is the sum of handling and driving labour cost, truck rental cost, and fuel cost. We assume a uniform biomass density within each agricultural statistical unit 
(province). Supplementary material - Section 3 presents assumptions and details on the calculation of transportation activity level.

$\mathrm{CO}_{2}$ and local air pollutants emissions occur from coal and straw combustion, coal and straw transportation, and straw open-burning. We exclude emissions from coal mining and rice cultivation. Health impact assessment considers the health damage of $\mathrm{SO}_{2}, \mathrm{NOx}$, and particulate matter (PM2.5) emission based on specific health damage cost per $t$.

\section{Results}

We ran the model using two cases. The first case refers to a newly built coal power plant, parameterized after the Mong Duong 1 plant in the North of Vietnam. The second case refers to a legacy plant, parameterized after the Ninh Binh plant, also in the North of Vietnam.

Table 1 below presents the terms of Equation 10 in total values over a ten years time horizon. The ten years time horizon is used because this is the investment linear amortization period under Vietnamese laws. The corporate tax rate is $20 \%$ [56]. In order to make the empirical model directly comparable to the theoretical model, we use a zero discount rate, so that results per year are just $1 / 10$ of the numbers in the table. The sensitivity analysis Figure 5 explores $5 \%, 10 \%$ and $15 \%$ discount rates.

Table 1: Business value of co-firing.

\begin{tabular}{|c|c|c|c|c|c|}
\hline & & & & New plant & Old plant \\
\hline (1) & $C_{\text {collect }}$ & Farmer's collection costs & $\mathrm{k} U S D$ & 27527 & 4853 \\
\hline (2) & $C_{\text {reseller }}$ & $\begin{array}{l}\text { Reseller's handling \& } \\
\text { transport cost }\end{array}$ & k USD & 5319 & 307 \\
\hline (3) & $C_{i n v}$ & Plant's investment cost & k USD & 2700 & 500 \\
\hline (4) & $C_{O M}-C_{O M}^{\circ}$ & Plant's extra O\&M cost & k USD & 44990 & 483 \\
\hline (5) & & Total costs $(=1+2+3+4)$ & $k U S D$ & 40536 & 6143 \\
\hline (6) & $Q_{\text {coal }}-Q_{\text {coal }}^{\circ}$ & Quantity of coal saved & $\mathrm{kt}$ & 1340 & 213 \\
\hline (7) & $p_{\text {coal }}$ & Cost of coal & $\mathrm{USD} / \mathrm{t}$ & 50.80 & 81.98 \\
\hline (8) & & value of coal saved $(=6 \times 7)$ & $k U S D$ & 68083 & 17425 \\
\hline (9) & V & Value of co-firing $(=8-5)$ & $\mathrm{k} U S D$ & 27547 & 11282 \\
\hline
\end{tabular}

The table shows that $V$ is positive in both cases, which validates the co-firing business case.

Table 2 gives another look at the results, as the value per $t$ of straw in reference to equations 3,5 , 9. 
Table 2: Business value of co-firing, average costs per $t$.

\begin{tabular}{|c|c|c|c|c|c|}
\hline & & & & New plant & Old plant \\
\hline (1) & WTA & Farmer's willingness to accept & $\mathrm{USD} / \mathrm{t}$ & 12.23 & 12.23 \\
\hline (2) & & Reseller's average cost & $\mathrm{USD} / \mathrm{t}$ & 2.36 & 0.77 \\
\hline (3) & WTP & Plant's willingness to pay & $\mathrm{USD} / \mathrm{t}$ & 26.83 & 41.44 \\
\hline (4) & & Potential surplus (3-1-2) & $\mathrm{USD} / \mathrm{t}$ & 12.24 & 28.44 \\
\hline (5) & Q & Biomass traded, total & $\mathrm{kt}$ & 2251.3 & 396.7 \\
\hline (6) & $\mathrm{V}$ & Value of co-firing $(=4 \times 5)$ & M USD & 27547 & 11282 \\
\hline
\end{tabular}

The willingness to pay for the new coal power plant ( Mong Duong 1 ) is $26.8 \mathrm{USD} / \mathrm{t}$, compared to 41.4 USD/t in the old plant (Ninh Binh). The main reason for this difference is that the coal type used in the old plant is anthracite, which has a high price (81.98 USD/t) compared to the coal used in the new plant $(50.80 \mathrm{USD} / \mathrm{t})$. The old plant uses sub-critical pulverized coal technology with low efficiency at only $22 \%$, the lowest among existing coal power plants in Vietnam; therefore, the coal consumption per kWh of the plant is high. As the old plant is from the 1970s, re-powering is needed soon to continue operating.

Figure 2 provides a visual representation of the results. The horizontal axis represents straw prices: the price at which farmers sell straw to the trader and the price at which the power plant buys straw from the trader. In Figure 2, the vertical axis shows the profit from implementing the deal. The increasing line is the farmer's gain from co-firing (Net Present Value - NPV of farmer's earning from selling straw), while the decreasing line is the plant's net profit (NPV of the plant with co-firing minus NPV of the plant without co-firing). WTA of the farmer is the straw selling price at which the farmer's benefit is zero. WTP of the plant is the straw buying price at which the plant's net income before taxes is zero. 


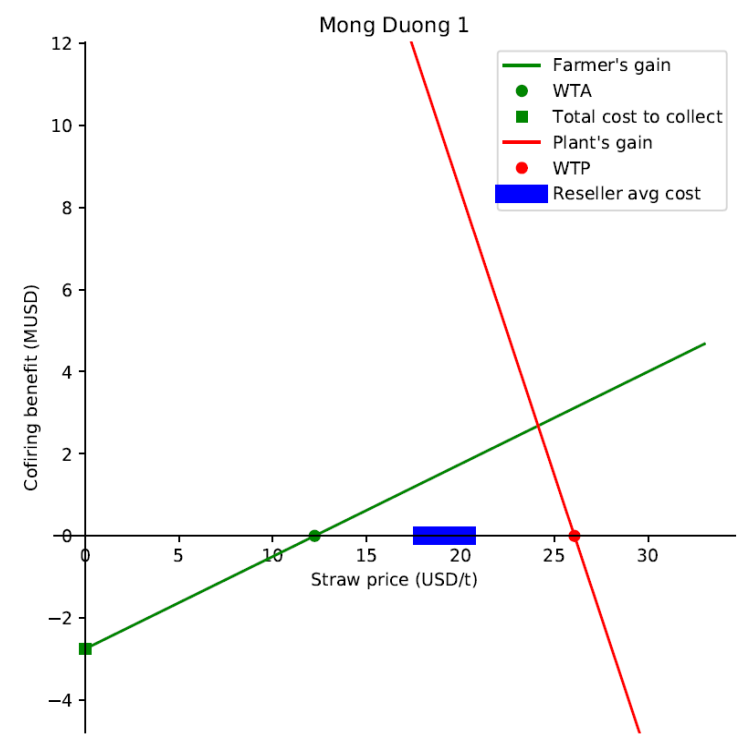

(a)

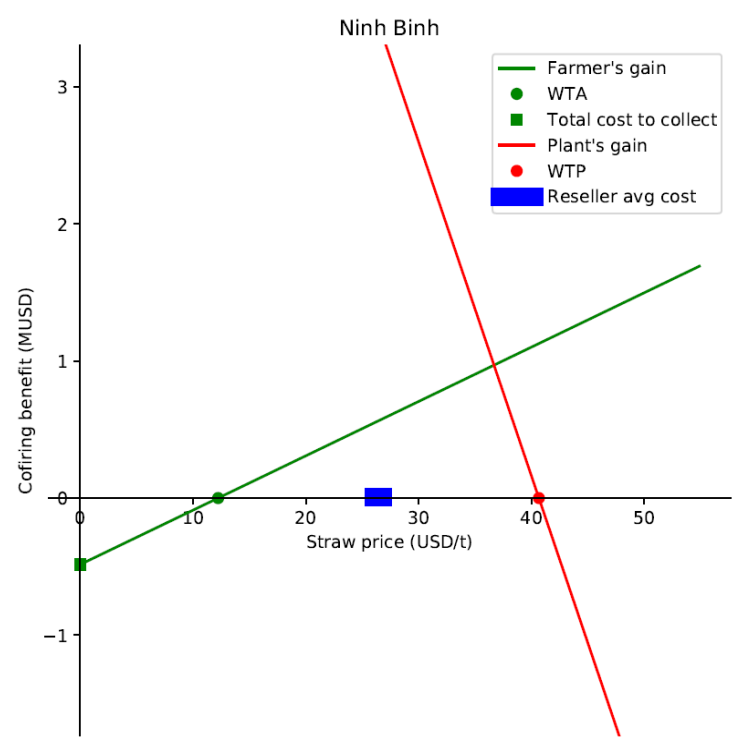

(b)

Figure 2. Economic analysis of co-firing results. (a) New plant case (Mong Duong 1 ); (b) old plant case (Ninh Binh ). Scales differ on the left and right cases for both axes.

Straw market prices influence the distribution of co-firing benefits among three stakeholders. When straw prices are high, the farmers profit the most. When straw prices shift to the left toward WTA, the profits from co-firing accrue mainly to the plant. Finally, the trader captures the most benefit if they can buy straw from the farmers at a low price and resell it to the plant at a high price.

We found that there was a business case since $V$ is positive. However, the significance of the business case depends on how large $V$ is for the stakeholders.

According to Trần Công Thắng [57], the profit from paddy production in Vietnam averages about 527 USD per hectare per season, 1054 USD per hectare per year. In our simulations, the business value of co-firing is $27 \mathrm{USD} / \mathrm{ha} / \mathrm{y}$ in the Mong Duong 1-like case, so that $V$ represents $2.5 \%$ of annual profit. The business value of co-firing is $63 \mathrm{USD} / \mathrm{ha} / \mathrm{y}$ in the Ninh Binh-like case so that $V$ represents $5.9 \%$ of annual profit. As an opportunity to improve the farmer's economic well being, this is marginal in both cases.

Mong Duong I's capacity, load factor, and electricity tariff imply an income of about 316 million USD per year. The business value of co-firing $V=2.7$ million USD per year is less than $1 \%$ of the plant's income. For Ninh Binh, the estimate $V$ represents at best $2.7 \%$ of income. As a fraction of profits, the numbers would be larger. Still, considering the risks involved with the investment, especially regarding the security and quality of supply, the business case for the power plant remains weak.

Moreover, all these percentages are upper bounds since the three segments of the value chain divide the business value among themselves. According to [57], farmers capture half of the profits in the rice value chain. We see little reason to transpose that to the straw value chain. 


\section{Results on air pollution: externalities more than business value}

So far, we examined the internal costs and benefits, those accruing to the three stakeholders. We now broaden the analysis to global and local air pollution externalities.

The system boundary for emissions estimates encompasses the combustion in power plants, coal and straw transportation, and straw burning in open fields. We exclude emissions from rice production and coal mining because we assume they are unchanged. The algebra is the same as in [53]: emissions are estimated proportional to activity levels. The results shown below use updated 2017 rice production statistics.

Following the IPCC guidelines [58], we model emissions from fuel combustion as the product of the amount of fuel consumed by an emission factor. Emissions from transportation are the product of the transportation activity level $(t \mathrm{~km})$ by the transportation emission factor $(\mathrm{kgCO} 2 \mathrm{e} / \mathrm{t} / \mathrm{km})$ [59]. Mong Duong I lies next to the coal mine, so we rounded down the coal transportation distance to $\mathrm{okm}$. For Ninh Binh, coal is delivered to the plant by barges through a distance of $200 \mathrm{~km}$.

Emissions are estimated using emission factors taken from literature, as listed in Table 4. These are emission factors for coal power plants before emission controls. Both the new and old coal power plants have electrostatic precipitators to reduce dust emissions. The filtering efficiencies are $99.6 \%$ in the former case and $99.2 \%$ in the latter. The new plant operates desulfurization technology using limestone with a system efficiency of about $98 \%$.

Figure 3 displays $\mathrm{NO}_{\mathrm{x}}, \mathrm{PM}_{2} .5, \mathrm{SO}_{2}$, and $\mathrm{CO}_{2}$ emissions without and with co-firing for the two cases under consideration. Each horizontal bar has three segments corresponding to the farmers, the reseller, and the power plant emissions. Table 3 multiplies the total emissions of each pollutant by specific health damage costs from [12] to obtain the value of the external reduction benefit. 
Co-firing changes greenhouse gas emissions in all system segments (see Figure 1), including fuels collection, transportation and combustion. According to our empirical technical model, the net effect of co-firing rice straw in these two coal-fired power plants is a greenhouse gas emissions reduction. Compared to coal, rice straw has a lower energy density and is collected from a more diffuse area. The costs and pollutions due to biomass transport are therefore a source of concern. Our results dismiss this concern. The magnitude of emissions from fuel transportation is small compared to emission reduction from combustion. Figure 3 shows that for biomass transport, only $\mathrm{NO}_{\mathrm{x}}$ and $\mathrm{CO}_{2}$ emissions matter, and only in the old plant case.

Moreover, co-firing biomass can reduce the costs and pollution due to coal transportation. Mong Duong lies next to the coal mine and receives coal from a conveyor belt. Hence, emissions from coal transportation activity are negligible. However, the straw is mobilized from sources up to $73 \mathrm{~km}$ away. The net result is that for Mong Duong 1 , in the co-firing case, the $\mathrm{CO}_{2}$ and air

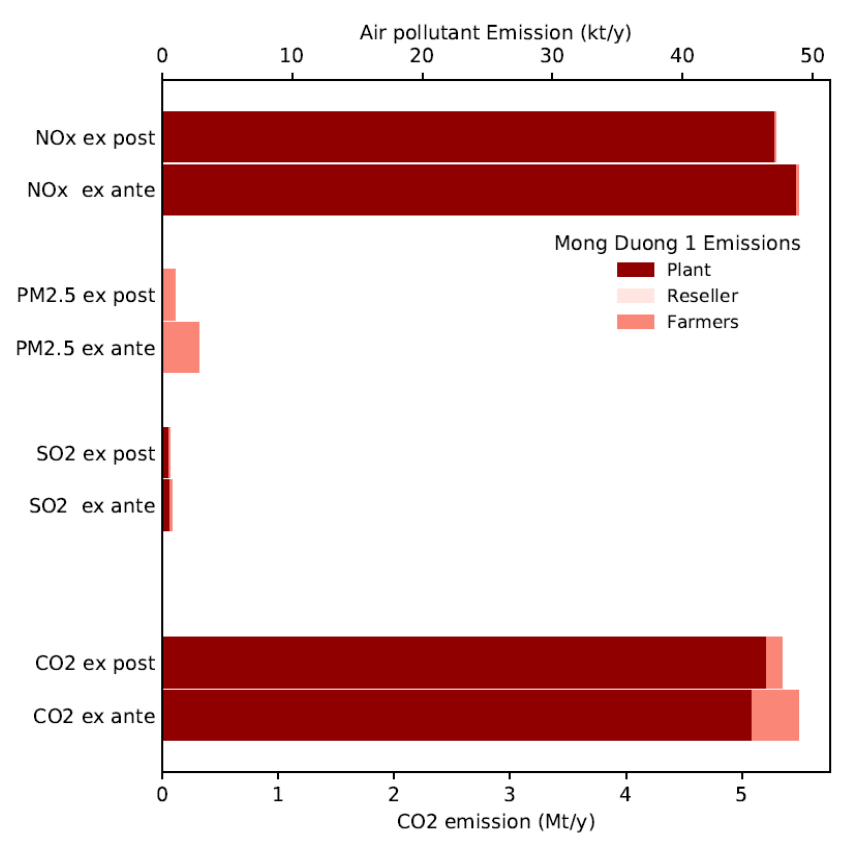

(a)

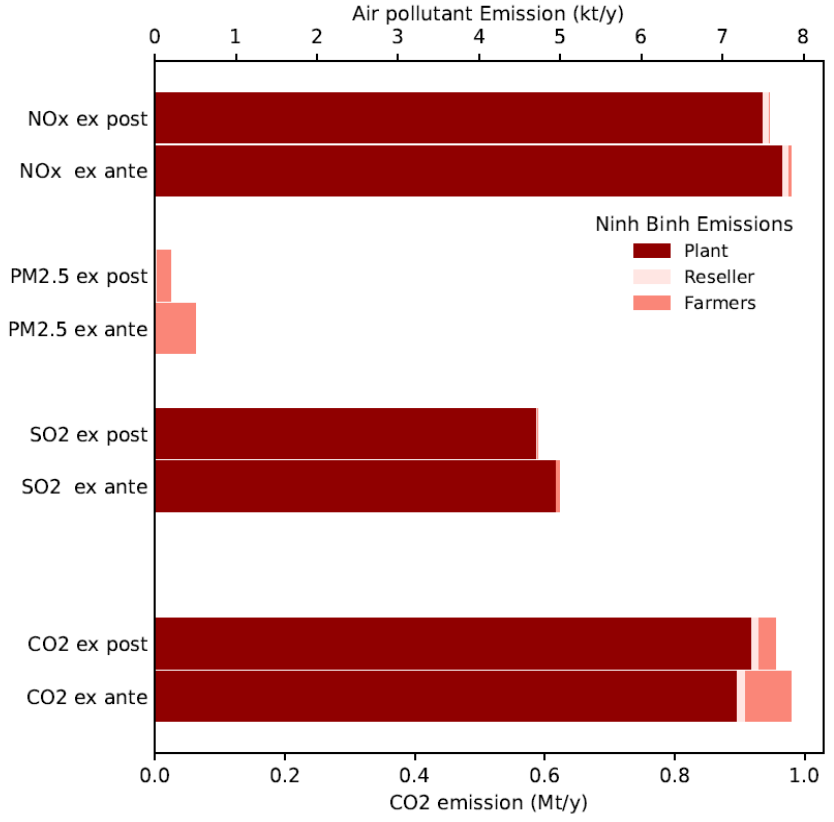

(b)

Figure 3: Pollutant emissions per year. (a) new plant case (Mong Duong 1-like), (b) old plant case (Ninh Binh-like). $\mathrm{NO}_{x}, \mathrm{PM}_{2.5}, \mathrm{SO}_{2}$ on the top scale in $\mathrm{kt} / \mathrm{y}, \mathrm{CO}_{2}$ on the bottom scale in Mt/y. Total emissions ex-post (with co-firing) are lower for all pollutants. Within each bar, the contribution of the three segments is shown. For example, the bottom pairs of broken bars show that $\mathrm{CO}_{2}$ emissions at the plant are higher ex-post, but this is more than compensated by reductions of emissions by the farmers.

Table 3: Net system emission reductions and their imputed monetary value of benefits.

\begin{tabular}{cccccc}
\hline Pollutant & $\begin{array}{c}\text { Specific } \\
\text { external cost } \\
\text { (USD/t) }\end{array}$ & $\begin{array}{c}\text { Emission } \\
\text { reductions (t/y) }\end{array}$ & $\begin{array}{c}\text { Value } \\
\text { (kUSD/y) }\end{array}$ & $\begin{array}{c}\text { Omission } \\
\text { reductions (t/y) }\end{array}$ & $\begin{array}{c}\text { Value } \\
\text { (kUSD/y) }\end{array}$ \\
\hline $\mathrm{NO}_{\mathrm{x}}$ & 5700 & 1732 & 9872 & 267 & 1523 \\
$\mathrm{PM}_{2.5}$ & 7200 & 1862 & 13405 & 309 & 2231 \\
$\mathrm{SO}_{2}$ & 5700 & 137 & 783 & 257 & 1466 \\
$\mathrm{CO}_{2}$ & 4 & 137032 & 548 & 24987 & 100 \\
\hline
\end{tabular}


pollutant emissions from transportation of fuels increase compared to the baseline case. The situation in Ninh Binh differs: straw travels less than $13.9 \mathrm{~km}$, while the coal mine is $200 \mathrm{~km}$ away. Thus the net result of co-firing is a reduction in transport emissions. Transportation activity in the co-firing case emits $543 \mathrm{tCO}_{2}$ less than the baseline case. The comparison between the two cases illustrates the effect of sourcing fuels locally.

In total, by co-firing straw with coal at $5 \%$, the new coal power plant could reduce $137 \mathrm{ktCO}_{2}$ per year. This number is $25 \mathrm{ktCO}_{2}$ per year for the old one. We use a social carbon value to quantify the benefit of $\mathrm{CO}_{2}$ emission reduction monetarily. There is no official carbon price for electricity production in Vietnam in 2020. We used $4 \mathrm{USD} / \mathrm{tCO}_{2}$ as the Draft Power Development Plan 8 [12] did. With this assumption, the climate-protection related external benefits of co-firing for the new plant case is 548 thousand USD/year, and for the old plant is 100 thousand USD/year. Internalizing the climate protection benefits with a $4 \mathrm{USD} / \mathrm{t}$ carbon tax would increase the business value of co-firing by $10-30 \%$. The business case would remain weak.

We now turn to the benefits of local air pollution mitigation. Co-firing reduces the emission of particulate matter $(\mathrm{PM}), \mathrm{SO}_{2}$, and $\mathrm{NO}_{\mathrm{x}}$ air-borne pollutants. As emission factors in Table 4 show, straw contains much less sulfur than coal, and its combustion produces less nitrous oxides. For example, a study [60] has reported S content at 0.03-0.18\% while that value for Vietnamese $4 \mathrm{~b}$ and $6 \mathrm{~b}$ coal is from $0.65-3 \%$ [61]. We use the same system's boundary to calculate the net emission reductions, accounting for transportation.

Table 4: Emission factors

\begin{tabular}{ccccc}
\hline & CO2 & SO2 & NOx & PM2.5 \\
\hline 6b_coal $(\mathrm{kg} / \mathrm{t})$ & $1,877.4^{\mathrm{a}}$ & $11.5^{\mathrm{b}}$ & $18.0^{\mathrm{b}}$ & $0.15^{\mathrm{k}}$ \\
4b_coal $(\mathrm{kg} / \mathrm{t})$ & $2,081.5^{\mathrm{a}}$ & $11.5^{\mathrm{b}}$ & $18.0^{\mathrm{b}}$ & $0.1^{\mathrm{k}}$ \\
straw_boiler $(\mathrm{kg} / \mathrm{t})$ & $1,674.0^{\mathrm{c}}$ & $0.18^{\mathrm{c}}$ & $3.43^{\mathrm{c}}$ & $6.28^{\mathrm{c}}$ \\
straw_open $(\mathrm{kg} / \mathrm{t})$ & $1,177.0^{\mathrm{d}}$ & $0.51^{\mathrm{e}}$ & $0.49^{\mathrm{d}}$ & $8.30^{\mathrm{d}}$ \\
diesel $(\mathrm{kg} / \mathrm{t})$ & $3,412.5^{\mathrm{f}}$ & $18.2^{\mathrm{f}}$ & $81.9^{\mathrm{f}}$ & $6.37^{\mathrm{f}}$ \\
conveyor_belt $(\mathrm{g} / \mathrm{tkm})$ & 0.0 & 0.0 & 0.0 & $0.085^{\mathrm{l}}$ \\
road_transport $(\mathrm{g} / \mathrm{tkm})$ & $110.0^{\mathrm{g}}$ & $0.00015^{\mathrm{h}}$ & $0.13^{\mathrm{h}}$ & $0.002^{\mathrm{h}}$ \\
barge_transport $(\mathrm{g} / \mathrm{tkm})$ & $71.0^{\mathrm{g}}$ & $0.25^{\mathrm{i}}$ & $6.34^{\mathrm{i}}$ & $0.40^{\mathrm{i}}$ \\
\hline $\mathrm{a}[58]^{\mathrm{b}}\left[{ }^{\mathrm{b}}[2]^{\mathrm{c}}[63]^{\mathrm{d}}[64]^{\mathrm{e}}[65]^{\mathrm{f}}[66]^{\mathrm{g}}[55]^{\mathrm{h}}[67]^{\mathrm{i}}[68]^{\mathrm{k}}[69]^{\mathrm{l}}[70]\right.$ & &
\end{tabular}

Table 3 and Figure 3 show that co-firing reduces $\mathrm{SO}_{2}, \mathrm{NO}_{x}$, and $\mathrm{PM}_{2.5}$ emissions in both systems. Co-firing in the new plant reduces $1732 \mathrm{t}$ of $\mathrm{NO}_{\mathrm{x}}, 1862 \mathrm{t}$ of $\mathrm{PM}_{2.5}$ and $137 \mathrm{t}$ of $\mathrm{SO}_{2}$ on a yearly basis. These numbers are equivalent to $3 \%$ of total $\mathrm{NO}_{\mathrm{x}}$ emissions, $8 \%$ of total $\mathrm{PM}_{2.5}$ emissions, and $0.8 \%$ of total SO2 emissions of Hanoi, Vietnam's capital, in 2015 estimated by [71]. Old plant, ten times smaller in installed capacity, have lower level of $\mathrm{NO}_{\mathrm{x}}$ and $\mathrm{PM}_{2.5}$ emissions reduction (267 t/y and $309 \mathrm{t} / \mathrm{y}$, respectively). However, $\mathrm{SO} 2$ emissions reduction is higher (257 t/year compared to $137 \mathrm{t} / \mathrm{y})$.

The share of dark red in the top bars of Figure 3 shows that combustion at the power plants causes almost all $\mathrm{NO}_{x}$ emissions in the system. These plants do not have $\mathrm{NO}_{x}$ control systems. Emissions of particulate matters happen mostly in the Farming segment of the system, as both 
plants have electrostatic precipitators to control $\mathrm{PM}_{2.5}$ emissions. $\mathrm{SO}_{2}$ emissions at the new plant are much smaller than in the old plant, which lacks a desulfurization system. This explains why the $\mathrm{SO}_{2}$ emission reduction benefits are more substantial at the old plant, even if it is ten times smaller.

Overall, for the new plant case, the external benefit of reducing local and global air pollution emissions is 24.6 million USD per year. The majority comes from reducing dust emission in the Farming segment. For the old plant case, the external benefit is 5.3 million USD per year. The majority is still from reducing dust. As the old plant lacks a desulfurization system, the $\mathrm{SO}_{2}$ emission reduction due to co-firing is proportionally more significant.

Figure 4 summarizes the costs and benefits analysis discussion so far. It allows us to compare the private business value discussed in section 5 and the externalities discussed in this section. As Equation 10 stated, the business value is the difference between the benefits arising from saving coal and the costs arising from biomass collection, its handling and transport, the investment in biomass processing at the coal plant (CAPEX), and the operating and maintenance costs (OPEX). The external benefit is the sum of $\mathrm{CO}_{2}, \mathrm{SO}_{2}, \mathrm{NOx}$, and dust $\left(\mathrm{PM}_{2.5}\right)$ reduction values. The critical results shown in Figure 4 are:

- The business value is positive with the parameters used. It is possible to satisfy the economic feasibility conditions for a straw market. We can find prices attractive for all three stakeholders at the same time.

- Environmental externalities are positive and several times the business value.

- The most important externality of co-firing straw is local air quality improvement.

- External benefits from carbon dioxide emission reduction appear small compared to air quality benefits. 


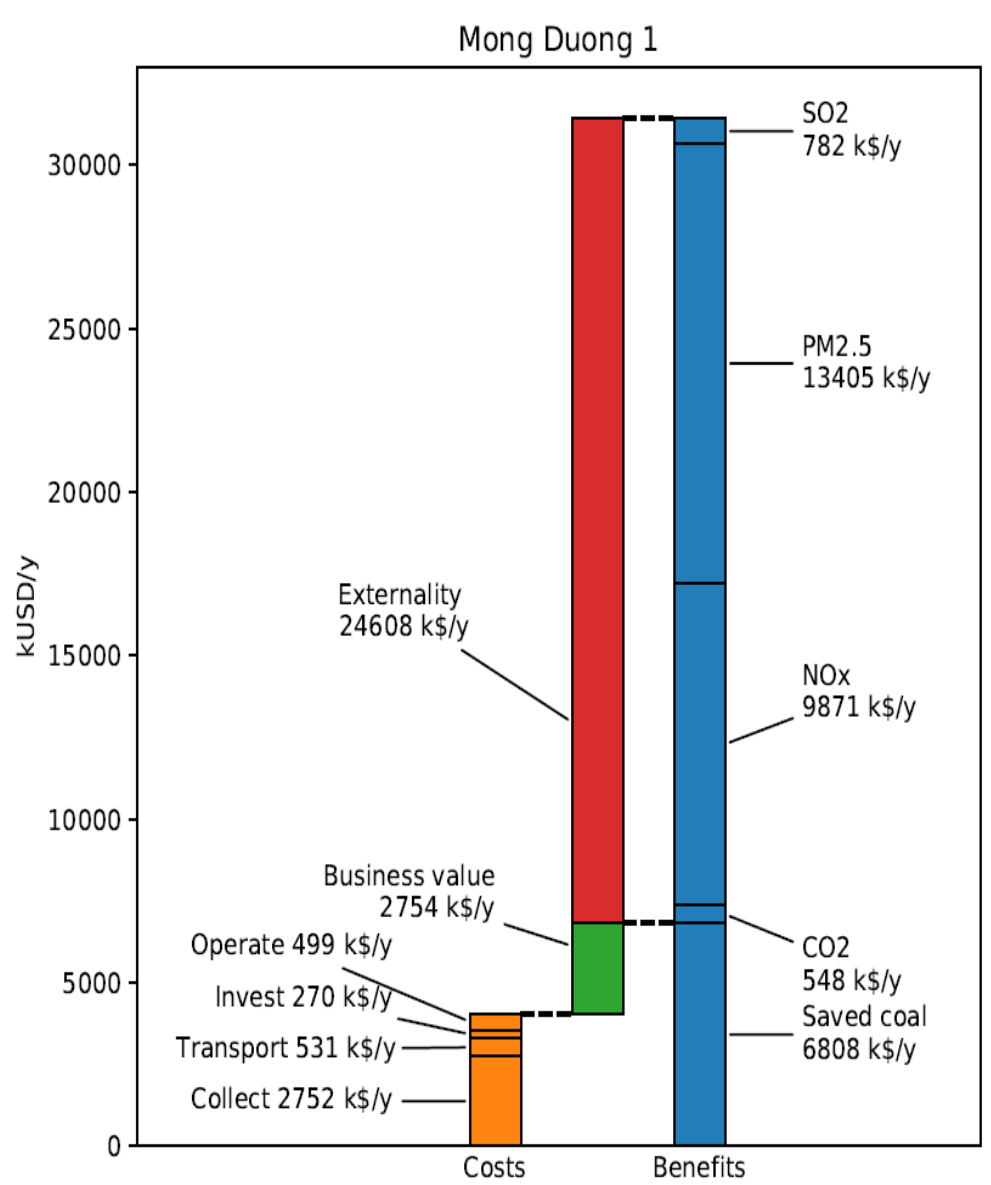

(a)

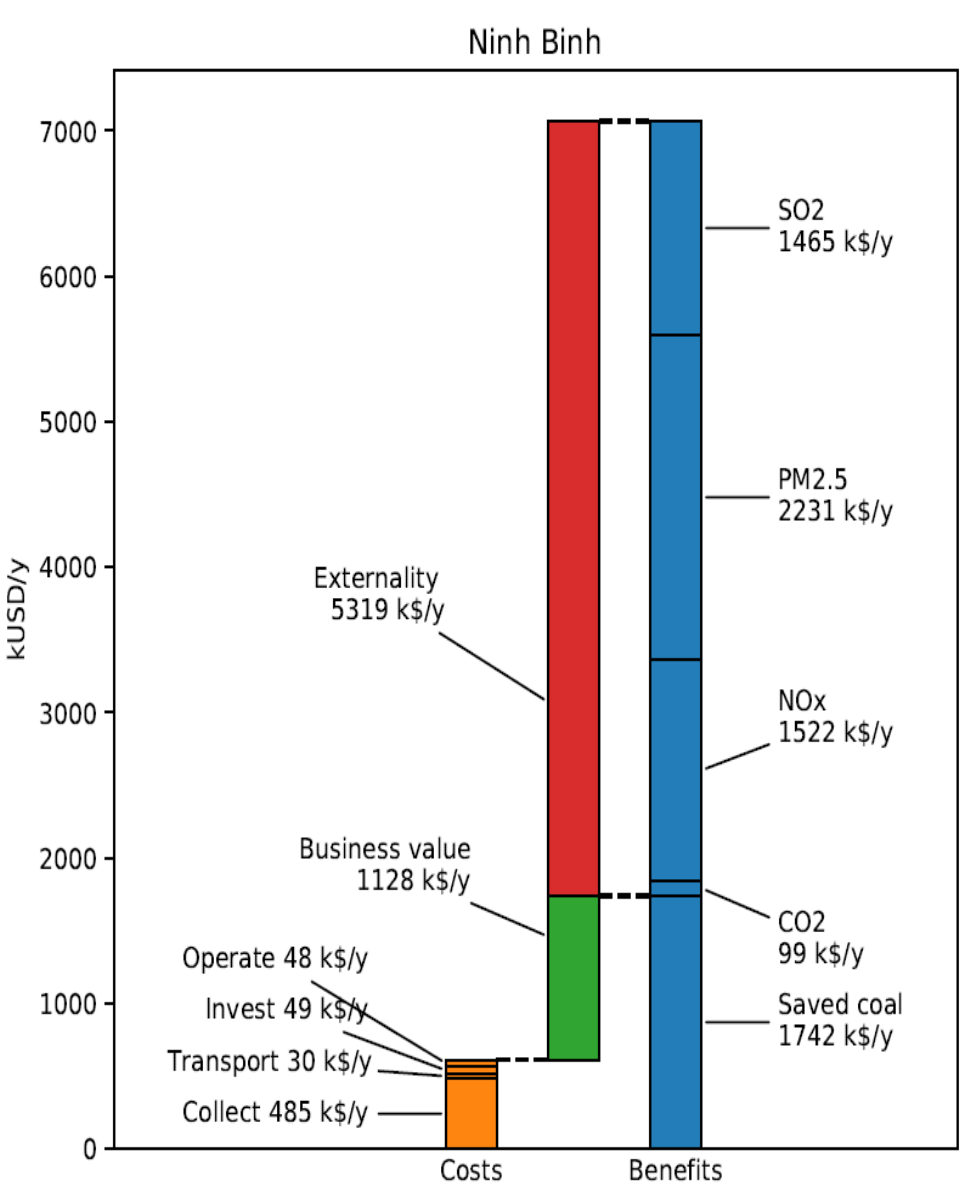

(b)

Figure 4. Cost-benefit analysis of co-firing. (a) New plant (Mong Duong 1), (b) older plant (Ninh Binh). Vertical scales are different in the two graphs due to the size of the two plants. Business value is the profit that the three stakeholders divide among themselves. The externality is the benefit of reducing the pollutants'emissions.

Figure 5 shows the one-parameter-at-a-time sensitivity analysis using uncertainty ranges in Table 5. Both the business value and the external value are the most sensitive to the rate of biomass co-firing examined. This is not surprising.

The discount rate is also a sensitive parameter in any investment analysis. Sensitivity to the discount rate goes in the opposite direction compared to other parameters. The coloured bar is to the left since increasing a discount rate decreases a net present value. In this figure, the discount rate is $10 \%$ per year for both private and external benefits, with a ten years time horizon. However, a public decision-maker may prefer a lower discount rate on the grounds that the primary concern is reducing pollution. Using a $5 \%$ per year discount rate, the external benefits increase from 151 MUSD to 190 MUSD in the new plant case.

The sensitivity analysis confirms the robustness of the results. Across a broad range of parameters, the Business value $V$ remains positive, and the External value remains larger than the Business value $V$. The error due to uncertainty on carbon value is smaller than the one due to uncertainty on external costs of local air pollution. 
We find that the business value is sensitive to the price of coal, (see Equation 10). By definition, external costs parameters are irrelevant. And while the prices of biomass at the field side and plant gate are essential for the stakeholders' economics, they do not change the business value of the sector as a whole.

The external value is directly sensitive to the external costs of pollutants. As Mong Duong 1 has sulfur emissions control equipment, the external costs of $\mathrm{SO}_{2}$ have less influence. With the uncertainty range for $\mathrm{CO}_{2}$ social value of 3 to $15 \mathrm{USD} / \mathrm{tCO}$, the sensitivity is modest compared to the uncertainty in local air pollutants. 

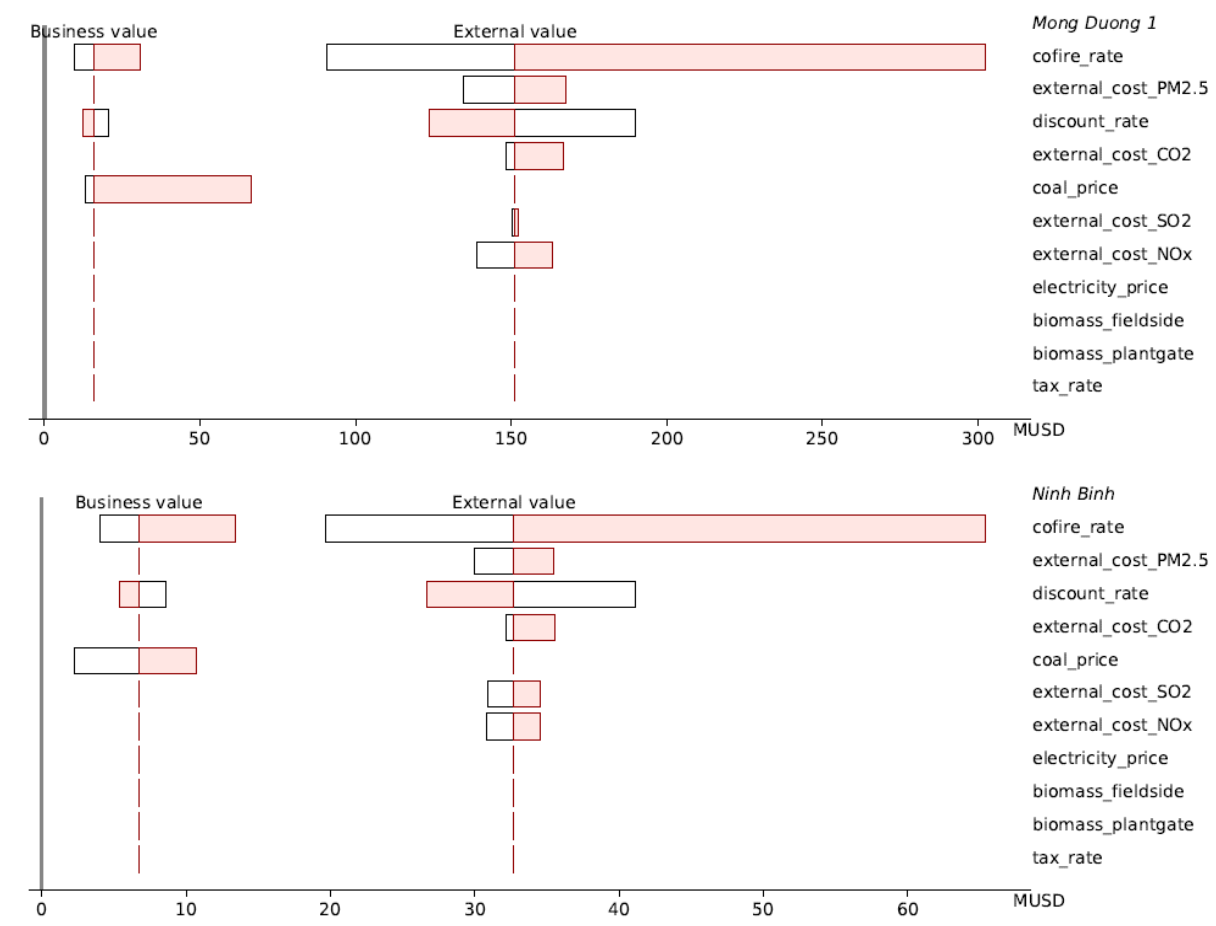

Figure 5: Sensitivity analysis of the Business value $V$ and the External value.

Parameters ranges in Table 5. The Business value is always positive. The External value is always larger than the Business value.

Table 5: Parameters of the sensitivity analysis.

\begin{tabular}{cccc}
\hline Mong Duong 1 & Low bound & Baseline & High bound \\
\hline discount_rate & 0.05 & 0.10 & 0.15 \\
tax_rate & 0.10 & 0.20 & 0.30 \\
coal_price & $47.5977 \mathrm{USD} / \mathrm{t}$ & $50.8038 \mathrm{USD} / \mathrm{t}$ & $112 \mathrm{USD} / \mathrm{t}$ \\
electricity_price & $0.051 \mathrm{UScent} / \mathrm{kWh}$ & $0.056 \mathrm{UScent} / \mathrm{kWh}$ & $0.090 \mathrm{UScent} / \mathrm{kWh}$ \\
external_cost_CO2 & $0.4 \mathrm{USD} / \mathrm{t}$ & $4 \mathrm{USD} / \mathrm{t}$ & $22.5 \mathrm{USD} / \mathrm{t}$ \\
external_cost_SO2 & $4560 \mathrm{USD} / \mathrm{t}$ & $5700 \mathrm{USD} / \mathrm{t}$ & $6840 \mathrm{USD} / \mathrm{t}$ \\
external_cost_PM2.5 & $5760 \mathrm{USD} / \mathrm{t}$ & $7200 \mathrm{USD} / \mathrm{t}$ & $8640 \mathrm{USD} / \mathrm{t}$ \\
external_cost_NOx & $4560 \mathrm{USD} / \mathrm{t}$ & $5700 \mathrm{USD} / \mathrm{t}$ & $6840 \mathrm{USD} / \mathrm{t}$ \\
open_burn_rate & 0.40 & 0.60 & 0.80 \\
biomass_plantgate & $17.6 \mathrm{USD} / \mathrm{t}$ & $22 \mathrm{USD} / \mathrm{t}$ & $38.4 \mathrm{USD} / \mathrm{t}$ \\
biomass_fieldside & $12.8 \mathrm{USD} / \mathrm{t}$ & $16 \mathrm{USD} / \mathrm{t}$ & $22.8 \mathrm{USD} / \mathrm{t}$ \\
cofire_rate & 0.03 & 0.05 & 0.10 \\
\hline Ninh Binh & Low bound & Baseline & High bound \\
\hline discount_rate & 0.05 & 0.10 & 0.15 \\
tax_rate & 0.10 & 0.20 & 0.30 \\
coal_price & $47.5977 \mathrm{USD} / \mathrm{t}$ & $81.9816 \mathrm{USD} / \mathrm{t}$ & $112 \mathrm{USD} / \mathrm{t}$ \\
electricity_price & $0.051 \mathrm{UScent} / \mathrm{kWh}$ & $0.075 \mathrm{UScent} / \mathrm{kWh}$ & $0.090 \mathrm{UScent} / \mathrm{kWh}$ \\
external_cost_CO2 & $0.4 \mathrm{USD} / \mathrm{t}$ & $4 \mathrm{USD} / \mathrm{t}$ & $22.5 \mathrm{USD} / \mathrm{t}$ \\
external_cost_SO2 & $4560 \mathrm{USD} / \mathrm{t}$ & $5700 \mathrm{USD} / \mathrm{t}$ & $6840 \mathrm{USD} / \mathrm{t}$ \\
external_cost_PM2.5 & $5760 \mathrm{USD} / \mathrm{t}$ & $7200 \mathrm{USD} / \mathrm{t}$ & $8640 \mathrm{USD} / \mathrm{t}$ \\
external_cost_NOx & $4560 \mathrm{USD} / \mathrm{t}$ & $5700 \mathrm{USD} / \mathrm{t}$ & $6840 \mathrm{USD} / \mathrm{t}$ \\
open_burn_rate & 0.40 & 0.60 & 0.80 \\
biomass_plantgate & $17.6 \mathrm{USD} / \mathrm{t}$ & $32 \mathrm{USD} / \mathrm{t}$ & $38.4 \mathrm{USD} / \mathrm{t}$ \\
biomass_fieldside & $12.8 \mathrm{USD} / \mathrm{t}$ & $19 \mathrm{USD} / \mathrm{t}$ & $22.8 \mathrm{USD} / \mathrm{t}$ \\
cofire_rate & 0.03 & 0.05 & 0.10 \\
\hline
\end{tabular}




\section{Results on employment: net jobs creation, mainly agricultural}

Having discussed the business value and the environmental externalities, we now turn to the local employment results.

We looked only at direct jobs created from co-firing straw. Co-firing requires labour in all three segments of the value chain: straw and coal production; straw and coal transportation; operation and maintenance of additional equipment needed for co-firing. As co-firing reduces the coal demand, the analysis also includes labour changes in the coal mining sector, with a caveat to be discussed in the last paragraph of this section. The mining job losses were estimated using the Coal mining productivity data published by the US Energy Information Administration [72].

We estimated the work needed for rice straw collection with the technological parameters current in Vietnam's campaigns: a straw winder needs one worker to operate and has a capacity of $6.57 \mathrm{t} /$ day, assuming an 8-hours working day. For transportation of straw, we estimated the total number of working-hour using the collecting radius as the distance for transport straw from sources to the plant by $20 t$ truck. We parametrized the average truck velocity at $45 \mathrm{~km} / \mathrm{h}$ according to road and transport conditions in Vietnam. The additional equipment used for cofiring within the power plant requires additional labour for operation and maintenance: we assume an extra 0.12 hour/MWh for that [73].

Table 6 shows the additional labour required by biomass co-firing. One full-time job equivalent amounts to 1560 hours per year. The base salary represents government regulations and market costs in 2019 in Vietnam. The key results are that most of the job created is from the straw collection and that the net total is positive: farmers gain more work than coal miners lose.

Table 6: Jobs creation and destruction in the co-firing scenario.

\begin{tabular}{cccccc}
\hline & Base salary & \multicolumn{2}{c}{ Mong Duong 1 } & \multicolumn{2}{c}{ Ninh Binh } \\
\hline & USD/hr & $\begin{array}{c}\text { Full-time job } \\
\text { equivalent }\end{array}$ & Total wages & $\begin{array}{c}\text { Full-time job } \\
\text { equivalent }\end{array}$ & Total wages \\
Straw collection & 3.7 & 175.7 & $1014.3 \mathrm{kUSD}$ & 31.0 & $178.7 \mathrm{kUSD}$ \\
Straw handling & 1.1 & 6.5 & $11.2 \mathrm{kUSD}$ & 1.1 & $2.0 \mathrm{kUSD}$ \\
Straw transportation & 2.1 & 14.4 & $47.7 \mathrm{kUSD}$ & 0.4 & $1,3 \mathrm{kUSD}$ \\
Operation and & 2.7 & 21.8 & $92.0 \mathrm{kUSD}$ & 2.2 & $9.1 \mathrm{kUSD}$ \\
Maintenance & & & & & \\
Mining & 5.6 & -34.4 & $-299.7 \mathrm{kUSD}$ & -5.4 & $-47.5 \mathrm{kUSD}$ \\
\hline Net Total & & 183.7 & $865.6 \mathrm{kUSD}$ & 29.2 & $143.6 \mathrm{kUSD}$ \\
\hline
\end{tabular}

The first key result is that most of the job created is from straw collection. It may be explained by the straw winder capacity in Vietnam. It is small, producing a 15-kg bale, compared to the type of machines used in more affluent countries. The small straw winder is compatible with the paddy fields in Vietnam: fragmented with modest areas. When there is a more mechanized way to collect rice straw, less work will be needed. 
The second key result - there is net job creation - may be underestimated. We included the loss of jobs in the mining sector for theoretical consistency. However, we doubt that co-firing will cause problems in the mining industry in Vietnam for two reasons. First, the coal mining industry is not limited by demand but rather by resource availability. Actual shortages that occurred in November 2018 [74] imply that the domestic supply did not meet demand. Second, while both plants are running on domestic coal, the country is a net importer at the national level. Vietnam prioritizes the consumption of domestic production, so if marginal reductions of the domestic coal demand impact jobs, it would be mostly jobs abroad.

\section{Summary and concluding remarks}

This text formalized the theoretical economic foundations of co-firing biomass in a coal power plant. It reviewed the international practical experience, including the situation in middleincome countries. Then it assessed the case for co-firing rice straw and coal using an integrated empirical model applied on two examples, an old and a new power plant in Vietnam. The five key results are:

1. The business value is positive. It is possible to find a straw price pair to satisfy the economic feasibility conditions for all three segments. However, the business value appears small from the stakeholders business analysis point of view, especially in front of the supply stability risk. The business case is weak, in line with the international experience that co-firing rarely occurs without incentives.

2. Environmental externalities are several times larger than the business value. Moreover, the value of external benefits would be even more significant if the public benefits were assessed using a public discount rate lower than the private one, as they should.

3. The most crucial externality of co-firing straw is local air quality improvement. Co-firing straw at the power plant reduces the air pollution generated by burning straw in open fields. It also improves the combustion of coal, reducing pollution at the plant.

4. External benefits of carbon dioxide emission reduction appear small compared to air quality benefits when assessed with a social carbon value of $6 \mathrm{USD} / \mathrm{tCO}_{2}$.

5. Regarding job creation, most of it is for straw collection. The capacity of straw winders used in Vietnam is small compared to the machines used in Europe or the US. Mechanization entails less work, more capital needs but requires large fields.

These results suggest that mandating co-firing would be socially justified. The total social benefits exceed the cost. The positive business value implies that, even without subsidies, as long as the players share the business value fairly, no one would lose money. It is unnecessary to invoke high social values of carbon to justify co-firing; the local air quality improvements are sufficient reasons. 
The upside of the weak business value is that the economic stakes are low. Whatever happens, co-firing will not impact much the production cost of electricity. This affordability contrasts with the wind and solar sectors, which receive feed-in tariffs well above the average production cost.

In some affluent countries, co-firing is justified as part of a national coal exit strategy, with a long-term view on biomass power generation with carbon capture and storage for negative emissions. In Vietnam, as in many middle-income countries, such argument may be too early to be heard. However, local air pollution is a severe problem for many tropical middle-income countries today. The infield burning of rice straw during harvesting season causes dangerous air pollution in the Red River Delta, where farmers disposed of $60-90 \%$ of the rice straw produced by burning in the field, according to Nguyen [75]. Straw open burning in Hanoi released $370 \mathrm{ktCO} 2,13.7 \mathrm{ktCO}, 0.67 \mathrm{ktSO} 2,0.35 \mathrm{ktNO} 2$ and $10.8 \mathrm{ktPM} 2.5$ in 2019 [76]. When the plant cofires the straw, the amount of straw disposed of will remain the same, but the plant's desulfurization and filtering systems reduce pollution. The Vietnam government has been trying to curb straw open-burning practices. Commoditizing straw as a fuel would give economic incentives to collect it instead of burning it in the field.

Co-firing technology is not used in Vietnamese power plants by mid-2019. However, the rapid expansion of coal-based electricity generation is a sustainability issue, and the rapid development of the wood and agriculture sector makes more biomass available. The Government of Vietnam [77] aims to have 12 TWh of electricity generation in 2030 from biomass, which is about $1.4 \mathrm{GW}$ of continuously operating power.

Should co-firing friendly policies be enacted in Vietnam, a more exhaustive study including various biomass feedstocks and all potential power plants should be conducted. Additional aspects would be interesting to research:

- Biomass sustainability. The simulations presented above assumed that only half of the residual biomass goes to the power plant. The environmental impact assessment of a cofiring policy should look at the agricultural implications of changing the nutrients cycle in more detail.

- Trade effects. Co-firing domestic agricultural waste is a way to reduce the reliance on imported coal. In the examples considered here, co-firing saves $134 \mathrm{kt}$ of coal per year for the larger plant. If the cost of imported coal is about $112 \mathrm{USD} / \mathrm{t}$ [78], then co-firing local biomass could save the trade balance 15 million USD per year there. On the other hand, in 2018, Vietnam exported 3.02 million tons of wood pellets worth 409 million USD, most of it to Japan and South Korea for co-firing [79], increasing I million tons over 2017. Developing the domestic market may reduce this flow.

- Regulation. How effective and efficient are norms, taxes, and other policy instruments to regulate coal power plants? As far as the policy goal is not limited to greenhouse gas emission reduction, tuning the parameters of Renewable Portfolio Standards to be more friendly to straw co-firing than, for example, large solar PV plants may be justified. 
In the end, the primary beneficiaries can be farmers. In the middle-income country context, cofiring straw in coal power plants is more an air quality and agricultural policy than an energy and climate policy.

\section{Acknowledgements}

Icons in Figure 2 used under Creative Commons license, created by Saishradda Malage, Verena Gutentag, Luis Prado, Aha-Soft, Anuar Zhumaev, Raz Cohen, Frederico Panzano, Phil Laver, Seuk Eumeu and Sebastian Langer from The Noun Project.

The authors co-wrote the model code and manuscript, with An Ha Truong doing the initial modelling and writing as part of her PhD study at USTH doctoral school. During the second revision of the manuscript, Hoang Anh Tran has provided an additional literature review on biomass and co-firing in Vietnam and other countries in Southeast Asia.

The authors declare no conflict of interest.

\section{References}

[1] Agbor E, Zhang X, Kumar A. A review of biomass co-firing in North America. Renew Sustain Energy Rev 2014;40:930-43. https://doi.org/10.1016/j.rser.2014.07.195.

[2] Cutz L, Berndes G, Johnsson F. A techno-economic assessment of biomass co-firing in Czech Republic, France, Germany and Poland. Biofuels, Bioproducts and Biorefining 2019;0. https://doi.org/10.1002/bbb.2034.

[3] Sahu SG, Chakraborty N, Sarkar P. Coal-biomass co-combustion: An overview. Renewable and Sustainable Energy Reviews 2014;39:575-86. https://doi.org/10.1016/j.rser.2014.07.106.

[4] Morrison B, Golden JS. Life cycle assessment of co-firing coal and wood pellets in the Southeastern United States. Journal of Cleaner Production 2017;150:188-96. https://doi.org/10.1016/j.jclepro.2017.03.026.

[5] Tillman DA. Biomass cofiring: the technology, the experience, the combustion consequences. Biomass and Bioenergy 2000;19:365-84. https://doi.org/10.1016/S0961-9534(00)00049-0.

[6] IRENA. Biomass for Power Generation. International Renewable Energy Agency (IRENA); 2012.

[7] IRENA. Biomass Co-firing-Technology Brief. IRENA and IEA-ETSAP; 2013.

[8] Wang X, Rahman ZU, Lv Z, Zhu Y, Ruan R, Deng S, et al. Experimental Study and Design of Biomass Co-Firing in a Full-Scale Coal-Fired Furnace with Storage Pulverizing System. Agronomy 2021;11:810. https://doi.org/10.3390/agronomy11040810.

[9] Koppejan J. Database of Biomass Cofiring initiatives - version 2.0. IEA Bioenergy - Task 32; 2017.

[10] An Ha Truong. Potential and socio-economic \& environmental impacts of co-firing technology in Vietnam. University of Science and Technology of Hanoi, 2020.

[11] Hannah Broadbent. Top 25 Coal Power Countries in 2020. Ember 2021. https://ember-climate.org/commentary/2021/04/14/top-25-coal-power-countries-in-2020/ (accessed May 29, 2021).

[12] Institute of Energy. Draft National Power Development Plan for 2021-2030 period with vision to 2045. Ministry of Industry and Trade; 2021.

[13] MONRE. Technical report for the National Determined Contributions of Vietnam. Ministry of Natural Resources and Environment; 2020.

[14] EVN. Vietnam electricity annual report 2015. Vietnam Electricity; 2015.

[15] Stich J, Ramachandran S, Hamacher T, Stimming U. Techno-economic estimation of the power generation potential from biomass residues in Southeast Asia. Energy 2017;135:930-42. https://doi.org/10.1016/j.energy.2017.06.162. 
[16] Lasko K, Vadrevu KP, Tran VT, Ellicott E, Nguyen TTN, Bui HQ, et al. Satellites may underestimate rice residue and associated burning emissions in Vietnam. Environ Res Lett 2017;12:085006. https:// doi.org/10.1088/1748-9326/aa751d.

[17] Hoang Anh Le, Tran Vuong Anh, Nguyen Tri Quang Hung. Air Pollutants estimated from rice straw open burning in Hanoi 2017.

[18] Miyake R, Burin E, Oliveira A, Bzuneck M, Bazzo E. Co-firing of Pulverized Coal and Rice Straw in a Drop Tube Furnace, 2013, p. 8.

[19] Dzikuć M, Piwowar A. Ecological and economic aspects of electric energy production using the biomass co-firing method: The case of Poland. Renewable and Sustainable Energy Reviews 2016;55:856-62. https://doi.org/10.1016/j.rser.2015.11.027.

[20] Fogarasi S, Cormos C-C. Technico-economic assessment of coal and sawdust co-firing power generation with CO2 capture. Journal of Cleaner Production 2015;103:140-8. https://doi.org/10.1016/j.jclepro.2014.07.044.

[21] Roni MS, Chowdhury S, Mamun S, Marufuzzaman M, Lein W, Johnson S. Biomass co-firing technology with policies, challenges, and opportunities: A global review. Renewable and Sustainable Energy Reviews 2017;78:1089-101. https://doi.org/10.1016/j.rser.2017.05.023.

[22] Bubholz M, Nowakowski R. Mapping of subsidy systems and future consumption of biomass. Svensk Fjärrvärme; 2010.

[23] Lüschen A, Madlener R. Economic viability of biomass cofiring in new hard-coal power plants in Germany. Biomass and Bioenergy 2013;57:33-47. https://doi.org/10.1016/j.biombioe.2012.11.017.

[24] Ofgem. Renewables Obligation (RO) Buy-out Price and Mutualisation Ceilings for 2020-21. Ofgem 2020. https://www.ofgem.gov.uk/publications-and-updates/renewables-obligation-ro-buy-out-priceand-mutualisation-ceilings-2020-21 (accessed April 29, 2020).

[25] Strauss W. 2020 global pellet markets outlook. Canadian Biomass Magazine 2020.

[26] Knapp S, Güldemund A, Weyand S, Schebek L. Evaluation of co-firing as a cost-effective short-term sustainable CO2 mitigation strategy in Germany. Energ Sustain Soc 2019;9:32. https://doi.org/10.1186/s13705-019-0214-3.

[27] Banja M, Sikkema R, Jégard M, Motola V, Dallemand J-F. Biomass for energy in the EU - The support framework. Energy Policy 2019;131:215-28. https://doi.org/10.1016/j.enpol.2019.04.038.

[28] Takanobu Aikawa. Sustainable biomass procurement for Japan’s bioenergy sector 2018.

[29] Streetz H. Germany’s Carbon Mitigation Plan With Biomass. Biomass Magazine 2019.

[30] Mei B, Wetzstein M. Burning wood pellets for US electricity generation? A regime switching analysis. Energy Economics 2017;65:434-41. https://doi.org/10.1016/j.eneco.2017.05.025.

[31] Repice R, Dunn DR, Zaidi J, Kopalek M, Long G, Berry R, et al. Monthly Energy Review - May 2020. US Energy Information Administration, Office of Energy Statistics, US Department of Energy; 2020.

[32] Government of Canada. $\quad$ Electricity facts 2020. https:/www.nrcan.gc.ca/science-data/data-analysis/energy-data-analysis/energy-facts/electricityfacts/20068 (accessed June 22, 2021).

[33] Silke Funke. North America's largest biomass power plant now operating. Sun \& Wind Energy 2014. https://www.sunwindenergy.com/bioenergy/north-americas-largest-biomass-power-plant-nowoperating (accessed June 22, 2021).

[34] Steph Wright. Largest Rice-Producing Countries. WorldAtlas 2020. https://www.worldatlas.com/articles/largest-rice-producing-countries.html (accessed June 22, 2021).

[35] Koppejan J, Baxter L. Global operational status on cofiring biomass and waste with coal Experience with different cofiring concepts and fuels. IEA Bioenergy - Task 32; 2006.

[36] Yasuo O, Fumiko Y, Phoumin H. Study on the Biomass and Coal Co-Combustion in the ASEAN Region. Indonesia: ERIA - Economic Research Institute for ASEAN and East Asia; 2919.

[37] Pribadi A. Terapkan Metode Co-Firing di PLTU, Ini Potensi Biomassa untuk Subtitusi Batubara Kementerian ESDM Republik Indonesia. Ministry of Energy and Mineral Resources; 2020.

[38] Ministry of Energy. Alternative Energy Development Plan. Thailand: Department of Renewable Energy Development and Energy Efficiency; 2015.

[39] Velasco MM. San Miguel to convert coal plants into biomass generating facilities. Manila Bulletin 2018. 
[40] Hu W. Development of co-firing biomass with coal in China under the low-carbon energy transition 2020.

[41] Matsumura EH, David PAM. PDE 2027. The ten-year energy expansion plan 2027 executive summary. Rio de Janeiro: Empresa de Pesquisa Energética (EPE); 2017.

[42] Papney DL. Policy of Ministry of Power for biomass utilization for power generation through cofiring in pulverized coal fired boilers. Thermal Engineering and Technology Development Division, Central Electricity Authority, Ministry of Power, Government of India; 2017.

[43] Pujari PK, Iuer MK, Jha IS. Proposed methodology for the estimation of electricity generated from biomass in biomas co-fired thermal power plants. New Delhi, India: Central Electricity Regulatory Commission; 2019.

[44] Johnston CMT, van Kooten GC. Economics of co-firing coal and biomass: An application to Western Canada. Energy Economics 2015;48:7-17. https://doi.org/10.1016/j.eneco.2014.11.015.

[45] Cuong TT, Le HA, Khai NM, Hung PA, Linh LT, Thanh NV, et al. Renewable energy from biomass surplus resource: potential of power generation from rice straw in Vietnam. Sci Rep 2021;11:792. https://doi.org/10.1038/s41598-020-80678-3.

[46] Nguyen Van Song; Thai Van Ha; Tran, Duc Thuan; Nguyen Van Hanh; Dinh Van Tien; et al. Development of Rice Husk Power Plants Based on Clean Development Mechanism: A Case Study in Mekong River Delta, Vietnam 2021.

[47] An Ha Truong, Patrizio P, Leduc S, Kraxner F, Hà Dương Minh. Reducing emissions of the fast growing Vietnamese coal sector: the chances offered by biomass co-firing. Journal of Cleaner Production 2019. https://doi.org/10.1016/j.jclepro.2019.01.065.

[48] Unchaisri T, Fukuda S, Phongphipat A, Saetia S, Sajjakulnukit B. Experimental Study on Combustion Characteristics in a CFB during Co-firing of Coal with Biomass Pellets in Thailand. International Energy Journal 2019;19.

[49] Suksankraisorn K, Patumsawad S, Fungtammasan B. Co-firing of Thai lignite and municipal solid waste (MSW) in a fluidised bed: Effect of MSW moisture content. Applied Thermal Engineering 2010;30:2693-7. https://doi.org/10.1016/j.applthermaleng.2010.07.020.

[50] Idris Muhammad Nurariffudin Mohd, Hashim Haslenda. Modeling Near-Term Bioenergy Strategy to Meet the Emission Target Production of Solid Biofuel to Scale Up Co-Firing. Chemical Engineering Transactions 2020;81:1099-104. https://doi.org/10.3303/CET2081184.

[51] Wahyudi WF, M.k IG. Economic and Financial Analysis of Cofiring the Coal Fired Steam Power Plant Capacity 660 MW with Biomass (Sawdust). Andalas Journal of Electrical and Electronic Engineering Technology 2021;1:27-30. https://doi.org/10.25077/ajeeet.v1i1.11.

[52] Shafie SM, Mahlia TMI, Masjuki HH. Life cycle assessment of rice straw co-firing with coal power generation in Malaysia. Energy 2013;57:284-94. https://doi.org/10.1016/j.energy.2013.06.002.

[53] An Ha Truong, Minh Ha-Duong. Impact of Co-firing Straw for Power Generation to Air Quality: A Case Study in Two Coal Power Plants in Vietnam. IOP Conf Ser: Earth Environ Sci 2018;159:012034. https://doi.org/10.1088/1755-1315/159/1/012034.

[54] De S, Assadi M. Impact of cofiring biomass with coal in power plants - A techno-economic assessment. Biomass and 2009;33:283-93. https://doi.org/10.1016/j.biombioe.2008.07.005.

[55] Binh NT, Tuan VA. Greenhouse Gas Emission from Freight Transport-Accounting for the Rice Supply Chain in Vietnam. Procedia CIRP 2016;40:46-9. https://doi.org/10.1016/j.procir.2016.01.051.

[56] Ministry of Finance. Circular no. 78/2014/TT-BTC on Guidelines to implement Decree no.218/2013/ ND-CP dated 26 December 2013 of the Government reulated and guidelines for implementation of Corporate Tax Law. 2014.

[57] Trần CT. Income distribution in Vietnam’s rice value chain. FFTC Agricultural Policy Articles 2017.

[58] Eggleston HS, Buendia L, Miwa K, Ngara T, Tanabe K. 2006 IPCC Guidelines for National Greenhouse Gas Inventories. IGES, Japan: IPCC; 2006.

[59] Alberici S, Hamelinck C. Annotated example of a GHG calculation using the EU Renewable Energy Directive methodology. Ecofys; 2010.

[60] Van Hung N, Maguyon-Detras MC, Migo MV, Quilloy R, Balingbing C, Chivenge P, et al. Rice Straw Overview: Availability, Properties, and Management Practices. In: Gummert M, Hung NV, 
Chivenge P, Douthwaite B, editors. Sustainable Rice Straw Management, Cham: Springer International Publishing; 2020, p. 1-13. https://doi.org/10.1007/978-3-030-32373-8_1.

[61] National Standard Technical Department TCVN/TC27 on Solid mineral fuels. National Standard TCVN 8910:2015 Commercial coal - Specifications. Hanoi: Ministry of Science and Technology of Vietnam; 2015.

[62] Eastern Research Group. Uncontrolled emission factor listing for criteria air. Point Sources Committee of the Emission Inventory Improvement Program; 2001.

[63] Cao G, Zhang X, Gong S, Zheng F. Investigation on emission factors of particulate matter and gaseous pollutants from crop residue burning. Journal of Environmental Sciences 2008;20:50-5. https://doi.org/10.1016/S1001-0742(08)60007-8.

[64] Nguyễn Thị Kim Oanh TLB. Characterization of particulate matter emission from open burning of rice straw. Atmospheric Environment (Oxford, England: 1994) 2011;45:493-502. https://doi.org/10.1016/j.atmosenv.2010.09.023.

[65] Nguyễn Thị Kim Oanh, Thuy Ly Bich, Danutawat Tipayarom, Christopher D. Simpson, David Hardie, L.-J. Sally Liu. Characterization of gaseous and semi-volatile organic compounds emitted from field burning of rice straw 2015.

[66] US-EPA. Chapter 3: Stationary internal combustion sources, Section 3.3 Gasoline and Diesdel Industrial engines. AP-42: Compilation of Air Emissions Factors, 1996.

[67] Vu Hoang Ngoc Khue, Ho Minh Dung, Nguyen Thoai Tam, Nguyen Thi Thuy Hang, Ho Quoc Bang. Inventory and mapping the air emissions from transportation activities in Ho Chi Minh city. Sci Tech Dev J - Nat Sci 2019;3:100-14. https://doi.org/10.32508/stdjns.v3i2.687.

[68] Van Dingenen R, Muntean M, Janssens-Maenhout G, Valentini L, Willumsen T, Guizzardi D, et al. Analysis of Air Pollutant Emission Scenarios for the Danube region. Joint Research Center; 2016.

[69] Nielsen O-K, Plejdrup M, Rentz O, Oertel D, Woodfield M. EMEP/EEA air pollutant emission inventory guidebook 2019 2019:116.

[70] NDEP. Guidance on Enmision Factor for the Mining Industry. Nevada Division of Environmental Protection; 2017.

[71] Amann M, Klimont Z, Truong AH, Rafaj P, Kiesewetter G, Nguyen B, et al. Future air quality in Hanoi and northen Vietnam. International Institute for Applied System Analysis and Vietnam Academy of Science and Technology; 2019.

[72] EIA. Table 7.7 Coal Mining Productivity, 1949-2011 (Short Tons per Employee Hour ) 2012. https:// www.eia.gov/totalenergy/data/annual/showtext.php?t=ptb0707 (accessed June 19, 2017).

[73] Singh V, Fehrs J. The work that goes into renewable energy. 2001.

[74] Chi Nam. Coal supply declines, thermal power plants at risk of suspension. VietNamNet Bridge 2018.

[75] Nguyen Mau Dung. Estimation of air pollutant emission from rice straw combustion in the open air in Red River Delta. Journal of Science and Development 2012;10:190-8.

[76] Pham T, Ly BT, Nghiem D, Pham P, Minh N-T, Tang N, et al. Emission factors of selected air pollutants from rice straw burning in Hanoi, Vietnam. Air Quality, Atmosphere \& Health 2021. https://doi.org/10.1007/s11869-021-01050-6.

[77] Nguyễn Tấn Dũng. Decision 2068/QD-TTg - Approving the development strategy of renewable energy of Vietnam by 2030 with a vision to 2050. Hanoi, Vietnam: The Government of Vietnam; 2015.

[78] General Department of Customs. Statistics of main imports by month. Ministry of Finance of Vietnam; 2018.

[79] Tô Xuân Phúc, Cao Thị Cẩm, Trần Lê Huy, Nguyễn Tôn Quyền, Huỳnh Văn Hạnh. Wood import and export of Vietnam 2018: one year look back and trend of 2019 2019:80. 